\title{
Production of oceanic nitrous oxide by ammonia-oxidizing archaea
}

\author{
C. R. Löscher ${ }^{1}$, A. Kock ${ }^{2}$, M. Könneke ${ }^{3}$, J. LaRoche ${ }^{2}$, H. W. Bange ${ }^{2}$, and R. A. Schmitz ${ }^{1}$ \\ ${ }^{1}$ Institut für Allgemeine Mikrobiologie, Christian-Albrechts-Universität Kiel, Am Botanischen Garten 1-9, \\ 24118 Kiel, Germany \\ ${ }^{2}$ Forschungsbereich Marine Biogeochemie, GEOMAR/Helmholtz-Zentrum für Ozeanforschung Kiel, \\ Düsternbrooker Weg 20, 24105 Kiel, Germany \\ ${ }^{3}$ Organic Geochemistry, MARUM, Universität Bremen, P.O. Box 330 440, 28334 Bremen, Germany
}

Correspondence to: C. R. Löscher (cloescher@ifam.uni-kiel.de)

Received: 29 January 2012 - Published in Biogeosciences Discuss.: 23 February 2012

Revised: 4 June 2012 - Accepted: 7 June 2012 - Published: 4 July 2012

\begin{abstract}
The recent finding that microbial ammonia oxidation in the ocean is performed by archaea to a greater extent than by bacteria has drastically changed the view on oceanic nitrification. The numerical dominance of archaeal ammonia-oxidizers (AOA) over their bacterial counterparts $(\mathrm{AOB})$ in large parts of the ocean leads to the hypothesis that AOA rather than AOB could be the key organisms for the oceanic production of the strong greenhouse gas nitrous oxide $\left(\mathrm{N}_{2} \mathrm{O}\right)$ that occurs as a by-product of nitrification. Very recently, enrichment cultures of marine ammonia-oxidizing archaea have been reported to produce $\mathrm{N}_{2} \mathrm{O}$.

Here, we demonstrate that archaeal ammonia monooxygenase genes $(a m o A)$ were detectable throughout the water column of the eastern tropical North Atlantic (ETNA) and eastern tropical South Pacific (ETSP) Oceans. Particularly in the ETNA, comparable patterns of abundance and expression of archaeal amoA genes and $\mathrm{N}_{2} \mathrm{O}$ co-occurred in the oxygen minimum, whereas the abundances of bacterial amoA genes were negligible. Moreover, selective inhibition of archaea in seawater incubations from the ETNA decreased the $\mathrm{N}_{2} \mathrm{O}$ production significantly. In studies with the only cultivated marine archaeal ammonia-oxidizer Nitrosopumilus maritimus $\mathrm{SCM} 1$, we provide the first direct evidence for $\mathrm{N}_{2} \mathrm{O}$ production in a pure culture of AOA, excluding the involvement of other microorganisms as possibly present in enrichments. $N$. maritimus showed high $\mathrm{N}_{2} \mathrm{O}$ production rates under low oxygen concentrations comparable to concentrations existing in the oxycline of the ETNA, whereas the $\mathrm{N}_{2} \mathrm{O}$ production from two AOB cultures was comparably low under similar conditions. Based on our findings, we hypothesize that
\end{abstract}

the production of $\mathrm{N}_{2} \mathrm{O}$ in tropical ocean areas results mainly from archaeal nitrification and will be affected by the predicted decrease in dissolved oxygen in the ocean.

\section{Introduction}

Atmospheric nitrous oxide $\left(\mathrm{N}_{2} \mathrm{O}\right)$ is a strong greenhouse gas (Forster et al., 2007) and a major precursor of stratospheric ozone depleting radicals (Ravishankara et al., 2009). The ocean is a major source of $\mathrm{N}_{2} \mathrm{O}$ contributing approximately $30 \%$ of the $\mathrm{N}_{2} \mathrm{O}$ in the atmosphere (Denman et al., 2007). Oceanic $\mathrm{N}_{2} \mathrm{O}$ is exclusively produced during microbial processes such as nitrification (under oxic to suboxic conditions) and denitrification (under suboxic conditions; Bange et al., 2010; Codispoti, 2010). The formation of $\mathrm{N}_{2} \mathrm{O}$ as a by-product of nitrification (oxidation of ammonia, $\mathrm{NH}_{3}$, via hydroxylamine, $\mathrm{NH}_{2} \mathrm{OH}$ to nitrite, $\mathrm{NO}_{2}^{-}$) was reported for ammonia-oxidizing bacteria (AOB) (Frame and Casciotti, 2010; Goreau et al., 1980). In the case of nitrifierdenitrification $\mathrm{NO}_{2}^{-}$can further be reduced to nitric oxide (NO) and $\mathrm{N}_{2} \mathrm{O}$ (Poth and Focht, 1985; Shaw et al., 2006). The accumulation of oceanic $\mathrm{N}_{2} \mathrm{O}$ is favored in waters with low oxygen $\left(\mathrm{O}_{2}\right)$ concentrations, which is attributed to an enhanced $\mathrm{N}_{2} \mathrm{O}$ yield during nitrification (Goreau et al., 1980; Stein and Yung, 2003). The frequently observed linear correlation between $\Delta \mathrm{N}_{2} \mathrm{O}$ (i.e. $\mathrm{N}_{2} \mathrm{O}$ excess) and the apparent oxygen utilization (AOU) is usually taken as indirect evidence for $\mathrm{N}_{2} \mathrm{O}$ production via nitrification (Yoshida et al., 1989). 
The traditional view that oceanic $\mathrm{NH}_{3}$ oxidation is exclusively performed by AOB has been challenged by (1) the presence of archaeal amoA genes in metagenomes of various environments (Lam et al., 2009; Schleper et al., 2005; Treusch et al., 2005; Venter et al., 2004), (2) the successful isolation of the ammonia-oxidizing archaeon $N$. maritimus (Könneke et al., 2005) and (3) the fact that archaea capable of ammonia oxidation have been detected in various oceanic regions throughout the water column and in sediments (Church et al., 2009; Francis et al., 2005; Lam et al., 2009; Santoro et al., 2010; Wuchter et al., 2006). Moreover, $N$. maritimus appears to be adapted to perform ammonia oxidation even under the oligotrophic conditions (MartensHabbena et al., 2009) that dominate in large parts of the open ocean. These observations point towards an important role of ammonia-oxidizing archaea (AOA, now constituting the novel archaeal lineage of Thaumarchaeota; BrochierArmanet et al., 2008; Spang et al., 2010) for the oceanic nitrogen $(\mathrm{N})$ cycle, which has been overlooked until recently (Francis et al., 2007; Schleper, 2010). Archaeal $\mathrm{N}_{2} \mathrm{O}$ production has been proposed to contribute significantly to the upper ocean $\mathrm{N}_{2} \mathrm{O}$ production in the central California Current and has recently been demonstrated to occur in two AOA enrichment cultures (Santoro et al., 2011). However, the ability of AOA to independently produce $\mathrm{N}_{2} \mathrm{O}$ as a by-product of nitrification has not been directly demonstrated in pure cultures or in the ocean.

The eastern tropical North Atlantic (ETNA) and the eastern tropical South Pacific (ETSP) Oceans represent two contrasting oceanic $\mathrm{O}_{2}$ regimes: while $\mathrm{O}_{2}$ concentrations in the ETNA are commonly above $40 \mu \mathrm{moll}^{-1}$, the ETSP regime is characterized by a pronounced depletion of $\mathrm{O}_{2}$ in intermediate waters between $\sim 75$ and $600 \mathrm{~m}$, resulting in an oxygen minimum zone (OMZ) with $\mathrm{O}_{2}$ concentrations close to or even below the detection limit $\left(\sim 2 \mu \mathrm{moll}^{-1}\right)$ of conventional analytical methods.

The amoA gene coding for the alpha subunit of the ammonia monooxygenase is present in archaea as well as in $\beta$ and $\gamma$-proteobacterial ammonia-oxidizers and is commonly used as a functional biomarker for this group (Hallam et al., 2006b; Schleper et al., 2005; Treusch et al., 2005; Venter et al., 2004). Thus, in order to identify whether archaeal or bacterial amoA was associated with the maximum in $\mathrm{N}_{2} \mathrm{O}$ concentration in the ocean, we determined the archaeal and bacterial amoA gene abundances and expression in relation to $\mathrm{N}_{2} \mathrm{O}$ concentrations along vertical profiles during three cruises (in February 2007, February 2008, and June 2010) to the ETNA and one cruise (in January 2009) to the ETSP. Further, we demonstrated $\mathrm{N}_{2} \mathrm{O}$ production in a pure culture of $N$. maritimus $\mathrm{SCM} 1$, which was found to be strongly $\mathrm{O}_{2}$ sensitive and is thus suggested to be of highest impact at times of ocean deoxygenation (Stramma et al., 2010). $\mathrm{N}_{2} \mathrm{O}$ production from pure cultures of the two marine nitrifying bacteria Nitrosococcus oceani $\mathrm{NC1} 10$ and Nitrosomonas marina
NM22 was low compared to the rates achieved by the archaeal isolate in our experiments.

\section{Methods summary}

\subsection{Hydrographic parameters and nutrients}

Samples for salinity, $\mathrm{O}_{2}$ concentrations and nutrients were taken from a 24-Niskin-bottle rosette equipped with a CTDsensor. Oxygen concentrations were determined following the Winkler method using 50 or $100 \mathrm{ml}$ sampling volumes, and salinity and nutrient concentrations were determined as described in Grasshoff et al. (1999).

\subsection{Determination of dissolved $\mathrm{N}_{2} \mathrm{O}$ concentrations}

Triplicate samples for $\mathrm{N}_{2} \mathrm{O}$ analysis were taken from CTD casts during the cruises P348 (February 2007), ATA03 (February 2008), P399 (June 2010) to the ETNA and M77/3 (January 2009) to the ETSP. $\mathrm{N}_{2} \mathrm{O}$ concentrations were measured with a GC headspace equilibration method as described in Walter et al. (2006); $\Delta \mathrm{N}_{2} \mathrm{O}$ and $\mathrm{AOU}$ were calculated as described therein.

\subsection{Molecular genetic methods}

\subsubsection{Sampling}

Seawater samples were taken from a minimum of 12 depths from the CTD casts. For the extraction of DNA and RNA a volume of about 21 seawater was rapidly filtered $(\sim 30 \mathrm{~min}$ filtration time for samples from the ETNA, for samples from the ETSP exact filtration volumes and times were determined and recorded continuously) through $0.2 \mu \mathrm{m}$ polyethersulfone membrane filters (Millipore, Billerica, MA, USA). The filters were immediately frozen and stored at $-80^{\circ} \mathrm{C}$ until further analysis.

\subsubsection{Nucleic acid purification}

DNA and RNA was extracted using the Qiagen DNA/RNA AllPrep Kit (Qiagen, Hilden, Germany) according to the manufacturers protocol with a small modification. A lysozyme treatment $\left(50 \mu \mathrm{g} \mathrm{ml}^{-1}\right.$ for $10 \mathrm{~min}$ at room temperature) followed by a proteinase $\mathrm{K}$ treatment was performed prior to starting the extraction. Extracts of DNA and RNA were quantified fluorometrically using a NanoDrop 2000 (Thermo Scientific Fischer). A treatment with Dnase I (Invitrogen, Carlsbad, CA) was performed with the extracted RNA to remove any residual DNA; purity of RNA was checked by 16S rDNA PCR amplification before reverse transcription. 
Table 1. Primers and PCR conditions: for real-time qPCR the initial denaturing step was 10 min at $95^{\circ} \mathrm{C}$, annealing temperatures were the same as in the end point PCRs, no final extension step took place, 40 cycles were performed followed by melting curve analysis. A fragment of $175 \mathrm{bp}$ was amplified in qPCRs of archaeal amoA.

\begin{tabular}{|c|c|c|c|c|c|}
\hline $\begin{array}{l}\text { Target } \\
\text { organism }\end{array}$ & $\begin{array}{l}\text { Target } \\
\text { gene }\end{array}$ & Oligonucleotide & Sequence $\left(5^{\prime} \rightarrow 3^{\prime}\right)$ & $\begin{array}{l}\text { PCR } \\
\text { conditions }\end{array}$ & Reference \\
\hline $\begin{array}{l}\beta \text {-proteobact. } \\
\text { ammonia-oxidizers }\end{array}$ & amoA & $\begin{array}{l}\operatorname{amoA} 1 F^{\prime} \\
\text { amoA2R } \\
\text { amoA-1F (qPCR) } \\
\text { amoAR_new (qPCR) }\end{array}$ & $\begin{array}{l}\text { GGGGTTTCTACTGGTGG } \\
\text { CCTCKGSAAAGCCTTCTTC } \\
\text { GGGGTTCTACTGGTGGT } \\
\text { CCCCTCGGCAAAGCCTTCTTC }\end{array}$ & $\begin{array}{l}94^{\circ} \mathrm{C} \text { for } 5 \mathrm{~min}, \\
30 \times\left(94^{\circ} \mathrm{C} \text { for } 20 \mathrm{~s},\right. \\
55^{\circ} \mathrm{C} \text { for } 1 \mathrm{~min}, 72^{\circ} \mathrm{C} \text { for } \\
1 \mathrm{~min}), 72^{\circ} \mathrm{C} \text { for } 10 \mathrm{~min}\end{array}$ & $\begin{array}{l}\text { Rotthauwe et } \\
\text { al. (1997) }\end{array}$ \\
\hline $\begin{array}{l}\gamma \text {-proteobact. } \\
\text { ammonia-oxidizer }\end{array}$ & amoA & $\begin{array}{l}\text { amoA3F } \\
\text { amoA4R } \\
\text { A189 (qPCR) } \\
\text { A682 (qPCR) }\end{array}$ & $\begin{array}{l}\text { GGTGAGTGGGYTAACMG } \\
\text { GCTAGCCACTTTCTGG } \\
\text { GGCGACTGGGACTTCTGG } \\
\text { GAACGCCGAGAAGAACGC }\end{array}$ & $\begin{array}{l}94^{\circ} \mathrm{C} \text { for } 5 \mathrm{~min}, \\
30 \times\left(94^{\circ} \mathrm{C} \text { for } 20 \mathrm{~s},\right. \\
48^{\circ} \mathrm{C} \text { for } 1 \mathrm{~min}, 72^{\circ} \mathrm{C} \text { for } \\
1 \mathrm{~min}), 72^{\circ} \mathrm{C} \text { for } 10 \mathrm{~min}\end{array}$ & $\begin{array}{l}\text { Purkhold et } \\
\text { al. (2000) }\end{array}$ \\
\hline $\begin{array}{l}\text { Archaeal } \\
\text { ammonia-oxidizers }\end{array}$ & amoA & $\begin{array}{l}\text { Arch-AmoAF } \\
\text { Arch-AmoAR } \\
\text { AamoA_for (qPCR) } \\
\text { AamoA_rev (qPCR) }\end{array}$ & $\begin{array}{l}\text { STAATGGTCTGGCTTAGACG } \\
\text { GCGGCCATCCATCTGTATGT } \\
\text { GGGCGACAAAGAAGAATAAACACTCGC } \\
\text { ACCTGCGGTTCTATCGGCGT }\end{array}$ & $\begin{array}{l}95^{\circ} \mathrm{C} \text { for } 5 \mathrm{~min}, \\
30 \times\left(94^{\circ} \mathrm{C} \text { for } 45 \mathrm{~s},\right. \\
50^{\circ} \mathrm{C} \text { for } 1 \mathrm{~min}, 72^{\circ} \mathrm{C} \text { for } \\
1 \mathrm{~min}), 72^{\circ} \mathrm{C} \text { for } 10 \mathrm{~min}\end{array}$ & $\begin{array}{l}\text { Francis et } \\
\text { al. (2005) } \\
\text { this study }\end{array}$ \\
\hline
\end{tabular}

\subsubsection{PCR and quantitative PCR}

The extracted RNA was reverse transcribed to cDNA by using the QuantiTect ${ }^{\circledR}$ Reverse Transcription Kit (Qiagen, Hilden, Germany) following the manufacturers' protocol.

Bacterial and archaeal $a m o A$ as marker genes for nitrification were PCR-amplified from DNA and cDNA. PCR and quantitative PCR conditions and primers are listed in Table 1. nirS, nirK and nosZ as marker genes for denitrification and the key functional marker gene for anammox, $h z o$, were PCR amplified according to established protocols (Lam et al., 2007; Schmid et al., 2008). The presence of key genes for anammox and denitrification was tested by PCR in the ETNA but quantified exclusively in samples of the ETSP. Assuming that the PCR detection system has a detection limit comparable to the respective qPCR (using the same Primers and PCR conditions), it should be in the range of 1 copy $1^{-1}$ for nirS up to 4 copies $1^{-1}$ in case of the other genes (deduced from the standard calibration curve in the qPCR assays). All PCRs were performed using $0.1 \mu \mathrm{l}$ FlexiTaq (Promega Corporation, USA).

Absolute quantification of bacterial and archaeal amoA was performed with standard dilution series; quantification was performed in duplicates. Standards for quantitative PCRs were obtained from Nitrosococcus oceani NC10, Nitrosomonas marina NM22 and NM51 for bacterial amoA and from an environmental clone for archaeal amoA (GenBank accession number JF796147). The specifity of the newly developed qPCR primers detecting archaeal amoA was checked according to the Miqe guidelines (Bustin et al., 2009) by cross amplification tests and re-cloning and sequencing of the products. Reactions were performed in a final volume of $25 \mu \mathrm{l}$ using $0.5 \mu \mathrm{l}$ of each primer, $6.5 \mu \mathrm{l}$ nuclease free water and $12.5 \mu \mathrm{l}$ SYBR qPCR Supermix W/ROX (Invitrogen,
Carlsbad, CA). Reactions were performed using an ABI 7300 Real Time PCR system (Applied Biosystems, Carlsbad, CA) according to Lam et al. (2007).

\subsubsection{Construction of clone libraries and phylogenetic analysis}

Cloning of PCR amplicons was performed using the Topo TA Cloning ${ }^{\circledR}$ Kit (Invitrogen, Carlsbad, CA) according to the manufacturer's instructions.

Sequencing was carried out by the Institute of Clinical Molecular Biology, Kiel. Sequences for archaeal amoA were analyzed using the ClustalW multiple alignment tool on a 495 bp fragment (sequences were submitted to GenBank under accession numbers JF796145-JF796179); sequence differences were set on a minimum of $5 \%$, and phylogenetic trees were made using distance-based neighbourjoining analysis (Saitou and Nei, 1987).

\subsection{Seawater incubations}

Seawater incubations were performed at three different stations in the ETNA (cruise P399). The $25 \mathrm{ml}$ serum bottles were filled with seawater from 200-250 m depth from the CTD casts, closed with an air-tight butyl rubber stopper and aluminum crimp-capped. Triplicate samples were taken to determine the initial $\mathrm{N}_{2} \mathrm{O}$ concentration; six bottles were incubated, one triplicate as a control and one triplicate was treated with $1 \mathrm{mM}$ of the hypusination inhibitor N1-guanyl-1,7-diaminoheptane ( $\mathrm{GC}_{7}$ ) (Jansson et al., 2000). Prior to the experiment, the sensitivity of AOA and $\mathrm{AOB}$ was checked using Nitrosopumilus maritimus SCM1, Nitrosococcus oceani $\mathrm{NC} 10$ and Nitrosomonas marina NM22 pure cultures. Different concentrations up to $1.5 \mathrm{mM} \mathrm{GC7}$ were applied to the cultures, which did not affect ammonia oxidation 

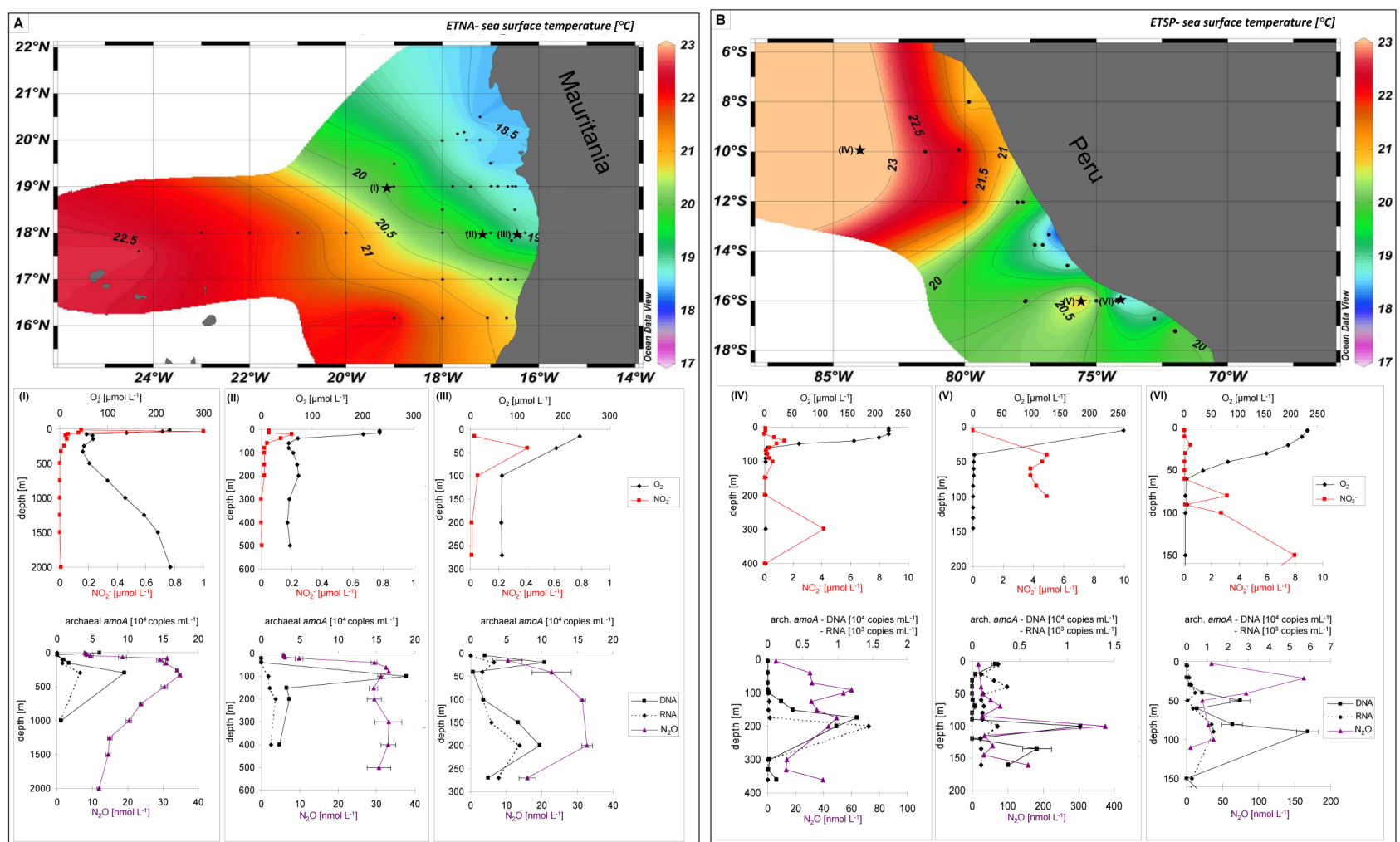

Fig. 1. Maps of sea surface temperatures (A) from the eastern tropical North Atlantic Ocean and (B) from the eastern tropical South Pacific Ocean. The locations of sampling stations are indicated with asterisks in the maps. Selected vertical profiles $(\mathrm{I}-\mathrm{VI})$ of $\mathrm{O}_{2}, \mathrm{NO}_{2}^{-}, \mathrm{N}_{2} \mathrm{O}$ (measured in triplicates) and archaeal amoA (measured in duplicates by qPCR) are shown; (I) and (IV) are located offshore, (II) and (V) are located on the continental slope, and (III) and (VI) are onshore/coastal stations.

or growth behavior in AOB. In contrast, $N$. maritimus showed a decrease in ammonia oxidation and growth when applying $\mathrm{GC}_{7}$ concentrations higher than $0.2 \mathrm{mM}$ and shut down nitrification when applying $\mathrm{GC}_{7}$ in a concentration of $\sim 0.8 \mathrm{mM}$.

Incubations were kept for the duration of the experiment $(24 \mathrm{~h})$ in the dark at $8^{\circ} \mathrm{C}$. The experiment was stopped by $\mathrm{HgCl}_{2}$ addition, followed by the determination of the final $\mathrm{N}_{2} \mathrm{O}$ concentrations.

\subsection{Culture experiments}

Pure cultures of $N$. maritimus, $N$. oceani and $N$. marina were grown in triplicates in $125 \mathrm{ml}$ serum bottles (containing $75 \mathrm{ml}$ culture and $50 \mathrm{ml}$ headspace) at $28^{\circ} \mathrm{C}$ according to Könneke et al. (2005) and Goreau et al. (1980). Serum bottles were closed with an air-tight butyl rubber stopper and aluminum crimp-capped. Cultures were kept for the duration of the experiment in the dark. Cell abundances from the triplicate samples were monitored by flow cytometry (FACScalibur, Becton, Dickinson) after staining with Sybr Green I (Invitrogen, Carlsbad). The accuracy of the flow cytometry was previously checked microscopically after staining the cells with the fluorescent DNA-binding dye 40, 6 0-diamidino-2-phenylindole (DAPI). Cultures were checked for contaminants microscopically and by $16 \mathrm{~S}$ rDNA analysis. While tests for the bacterial 16S rDNA gene were negative, the analysis of 84 clones of archaeal 16S rDNA showed that all analyzed sequences matched the identity of the N.maritimus culture. The 16S rDNA gene was PCR amplified with universal primers, followed by Topo TA cloning and sequencing. Sequence analysis did not show any contaminants.

$\mathrm{N}_{2} \mathrm{O}$ concentrations were measured by gas chromatography using the headspace method as described above, oxygen concentrations were determined using Winkler titration in $50 \mathrm{~mL}$ Winkler bottles. $\mathrm{NH}_{4}^{+}$and $\mathrm{NO}_{2}^{-}$concentrations were determined at several time points over the complete incubation time frame (Grasshoff et al., 1999). In order to exclude chemical $\mathrm{N}_{2} \mathrm{O}$ production from the medium, cultures toxified with mercury chloride were measured in parallel; no $\mathrm{N}_{2} \mathrm{O}$ production could be detected.

Isotopomeric studies were performed with cultures of 0.51 volume, grown in serum bottles supplemented with ${ }^{15} \mathrm{NH}_{4}^{+}$ $\left(10 \%\right.$ of total $\left.\mathrm{NH}_{4}^{+}\right)$. Measurements were performed as described in Fehling and Friedrichs (2010) and Nakayama et al. (2007). 

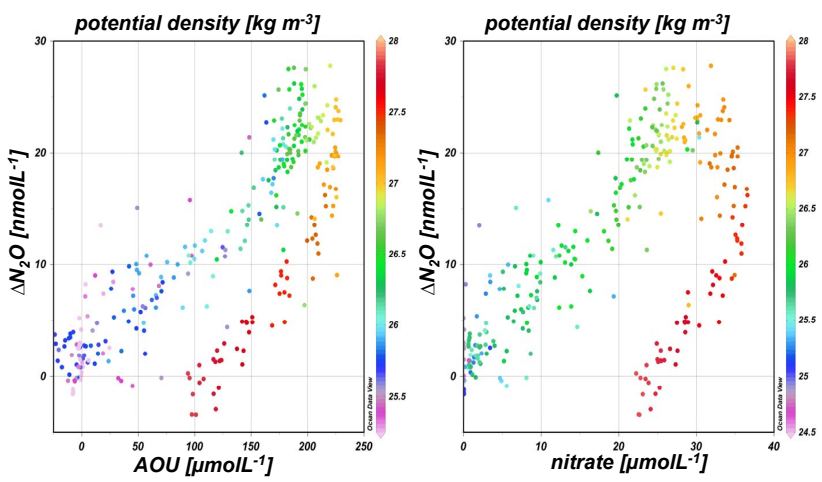

Fig. 2. $\Delta \mathrm{N}_{2} \mathrm{O}$ versus the apparent oxygen utilization (AOU) and nitrate in the ETNA (data from cruises ATA03, P348 and P399), the potential density is colour-coded.

\section{Results and discussion}

\subsection{Vertical distribution of $A O A$ and $A O B$ along $\mathrm{N}_{2} O$ depth profiles}

Vertical profiles of $\mathrm{N}_{2} \mathrm{O}$ showed a distribution with concentrations between 10 and $35 \mathrm{nmoll}^{-1}$ in the ETNA, whereas the $\mathrm{N}_{2} \mathrm{O}$ concentrations in the ETSP were in the range from 10 to $374 \mathrm{nmoll}^{-1}$ (Fig. 1). In the majority of the sampled stations in the ETNA and the ETSP, the accumulation of dissolved $\mathrm{N}_{2} \mathrm{O}$ was associated with minimum $\mathrm{O}_{2}$ concentrations, as expected (Codispoti, 2010). Maximum $\mathrm{N}_{2} \mathrm{O}$ concentrations in the ETNA were generally lower compared to the ETSP, probably as a result of extremely depleted $\mathrm{O}_{2}$ concentrations in the ETSP below $75 \mathrm{~m}$ resulting in enhanced $\mathrm{N}_{2} \mathrm{O}$ accumulation (Suntharalingam et al., 2000; Codispoti, 2010).

The well-established linear correlation between $\Delta \mathrm{N}_{2} \mathrm{O}$ and $\mathrm{AOU}$ as well as $\mathrm{NO}_{3}^{-}$(Nevison et al., 2003) was found for the ETNA (Fig. 2), indicating that nitrification was the likely pathway for $\mathrm{N}_{2} \mathrm{O}$ production. A comparable pattern of the distribution of archaeal amoA genes and $\mathrm{N}_{2} \mathrm{O}$ was observed in the water column of the ETNA (Fig. 3), strongly suggesting a correlation between AOA abundance and $\left[\mathrm{N}_{2} \mathrm{O}\right]$ accumulation (Pearson correlation coefficient $r=0.63$, statistical significance is indicated) in the layers with low $\mathrm{O}_{2}$ (Fig. 4). The key genes for denitrification and anammox (nirS and nirK coding for nitrite reductases and $h z o$ coding for the hydrazine oxidoreductase; Lam et al., 2007; Schmid et al., 2008) were not present in detectable amounts. A cooccurrence of $\mathrm{N}_{2} \mathrm{O}$ and archaeal amoA genes was detected at certain depths, e.g. at profile $\mathrm{V}$ at $100 \mathrm{~m}$ water depth (Fig. 1) in the ETSP, but was not a general feature, possibly resulting from additional $\mathrm{N}_{2} \mathrm{O}$ production via other processes such as denitrification, nitrifier-denitrification or anammox (Kartal et al., 2007) at present suboxic conditions. The presence of key genes of anammox and denitrification assayed and predominantly detected at coastal stations of the ETSP but also present in large parts of the area off Peru further points to

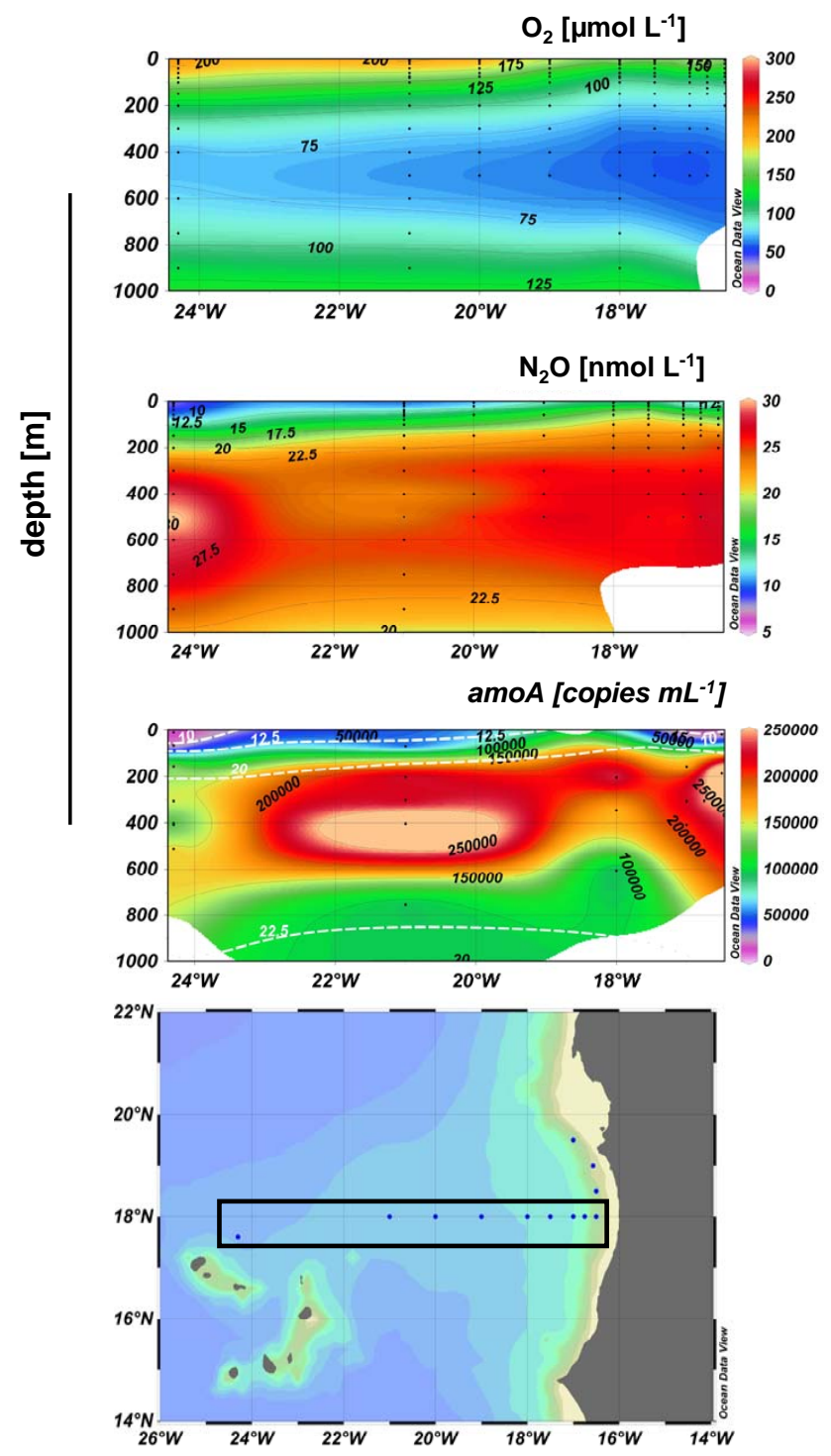

Fig. 3. Distribution of $\mathrm{O}_{2}\left[\mu \mathrm{mol} 1^{-1}\right], \mathrm{N}_{2} \mathrm{O}\left[\mathrm{nmol}^{-1}\right]$ and archaeal amo $A$ [copies $\mathrm{ml}^{-1}$ ] along $18^{\circ} \mathrm{N}$ in the ETNA, detected during the cruise P399. Archaeal $a m o A$ abundances are overlaid by the detected $\mathrm{N}_{2} \mathrm{O}$ concentration (dashed white line).

an active contribution of mixed processes to $\mathrm{N}_{2} \mathrm{O}$ production in the ETSP (the complete dataset of the ETSP can be seen in Löscher (2011). $\mathrm{N}_{2} \mathrm{O}$ production by mixed processes may explain the lack of correlation between $\Delta \mathrm{N}_{2} \mathrm{O}$ and AOU as well as $\mathrm{NO}_{3}^{-}$in the ETSP (Ryabenko et al., 2012). Gene abundances of archaeal amoA in the ETNA and ETSP were detectable throughout the water column and reached values of up to $1.9 \times 10^{5}$ and $6 \times 10^{4}$ copies $\mathrm{ml}^{-1}$, respectively (Fig. 1). Gene abundances of $\beta$ - and $\gamma$-proteobacterial amoA were much lower (up to 950 and 1178 copies $\mathrm{ml}^{-1}$ in the ETNA and ETSP, respectively; Fig. S1 in the Supplement). This is in line with previous studies reporting 1-4 orders of magnitude higher abundances of AOA than AOB 


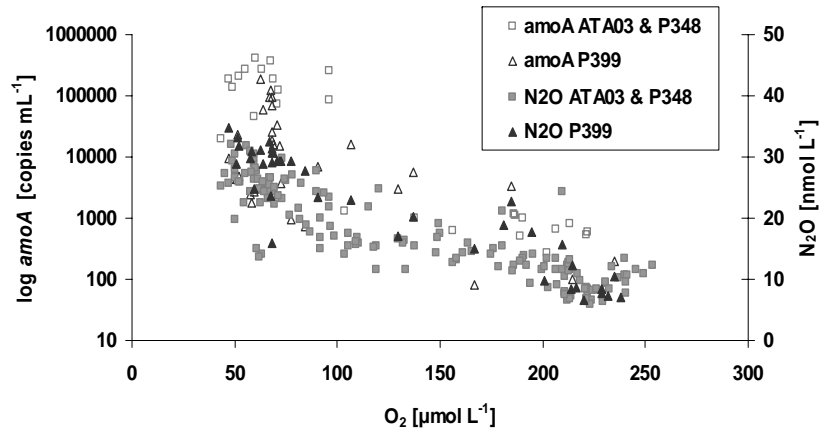

Fig. 4. Archaeal amoA and $\mathrm{N}_{2} \mathrm{O}$ versus $\mathrm{O}_{2}$ in the ETNA (data from the cruises ATA03, P348 and P399/2). A similar trend has been detected during the three cruises.

in various oceanic regions (Wuchter et al., 2006; Santoro et al., 2010; Lam et al., 2009; Francis et al., 2005; Church et al., 2009). Thus, we hypothesize that a significant part of the $\mathrm{N}_{2} \mathrm{O}$ production occurs via archaeal nitrification in the ETNA and might also be present in parts of the water column of the ETSP. A difference of one order of magnitude between archaeal amoA copies in RNA and in DNA has been observed in vertical profiles of the ETSP, with copy numbers up to $7 \times 10^{4}$ copies $\mathrm{ml}^{-1}$ in the DNA and up to $1.5 \times 10^{3}$ copies $\mathrm{ml}^{-1}$ in the RNA. A similar tendency is detectable in the ETNA; however, the difference is less pronounced compared to the ETSP. This discrepancy, already reported by Lam et al. (2009), is hypothesized to be due to a diurnal cycle of ammonia-oxidation and therefore changing amoA expression. Moreover, a sampling bias due to comparably long filtration times (up to $30 \mathrm{~min}$ ) might have led to RNA degradation, as previous studies reported transcript half-lives of down to $0.5 \mathrm{~min}$ in Prochlorococcus (Steglich et al., 2010).

\subsection{Phylogenetic diversity of archaeal amoA}

The diversity of AOA present in the ETNA was determined based on the analysis of $\sim 300 \mathrm{amoA}$ sequences from 15 stations of 3 cruises (P348, ATA03, and P399). Sequences were derived from up to 3 depths between the ocean surface and $1000 \mathrm{~m}$, which showed archaeal amoA presence by PCR. The sequences split into two main clusters, with sequences from the $\mathrm{O}_{2}$ minimum clustering mainly in cluster B (Fig. 5, Table $\mathrm{S} 1$ in the Supplement). Only $11.5 \%$ of sequences derived from samples from the $\mathrm{O}_{2}$ minimum fall into cluster A. Sequences derived from depths between the surface and the upper oxycline were present in both clusters to equal amounts (Fig. 5, Table S1 in the Supplement). In the ETSP, sequences from within as well as from depths above the OMZ separated into both clusters, with the majority of absolute sequence numbers from the OMZ affiliating with cluster B (Fig. 5, Table $\mathrm{S} 1$ in the Supplement), as already observed for the sequences from the $\mathrm{O}_{2}$ minimum in the Atlantic Ocean.

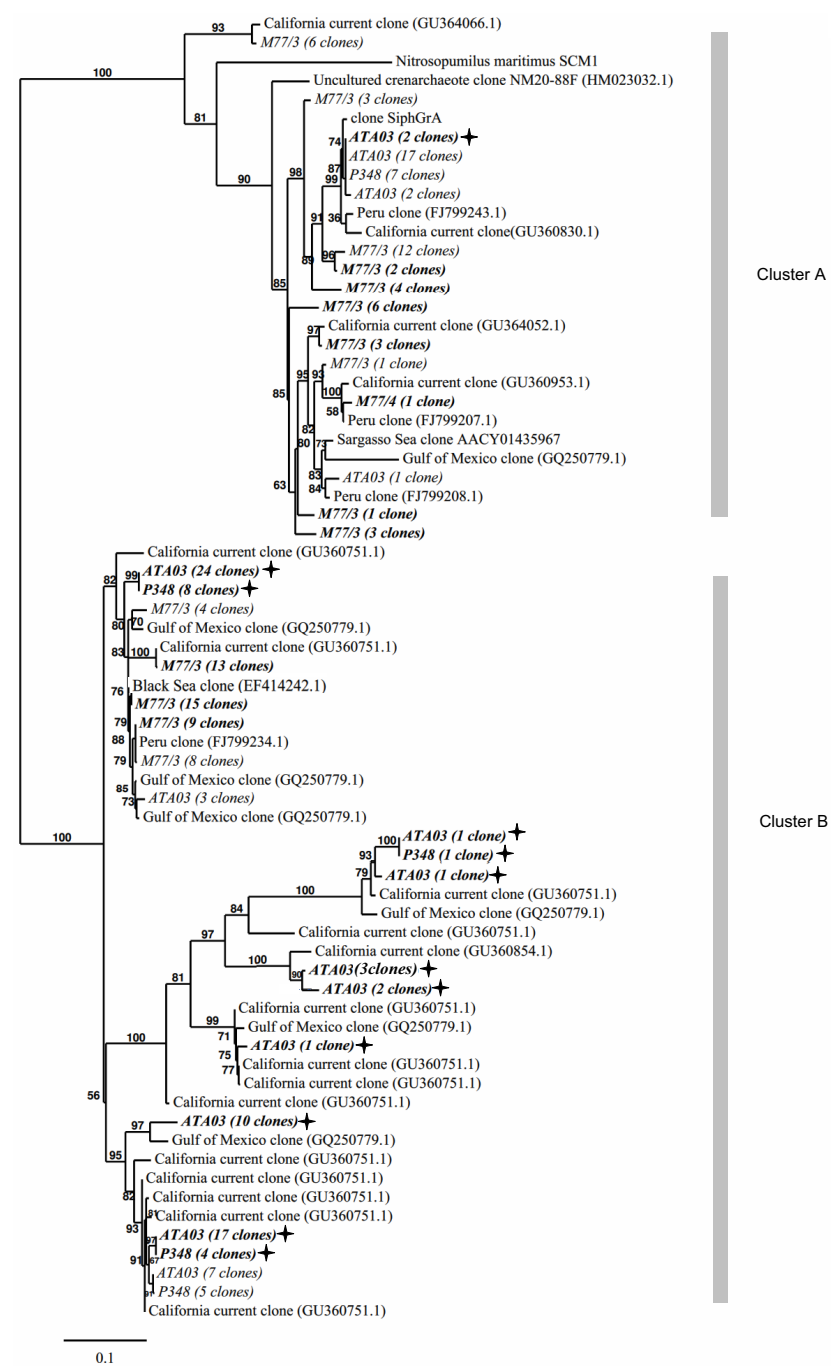

Fig. 5. Distance-based neighbour-joining phylogenetic tree of archaeal amoA sequences from the ETNA (cruises ATA03 and P348) and ETSP (cruise M77/3). Sequences derived from the oxygen minimum zone (OMZ) of the ETNA are in italics, bold and marked with solid stars; sequences from above the $\mathrm{OMZ}$ are in italics. Sequences from the OMZ of the ETSP are in italics and bold; sequences from above the OMZ are in italics.

\subsection{Potential importance of cluster $B$ affiliated Thaumarchaeota for $\mathrm{N}_{2} \mathrm{O}$ production}

The distribution of archaeal $a m o A$ genotypes along vertical profiles in the ETNA with the majority of cluster B sequences present in clone libraries from the OMZ suggest a production of $\mathrm{N}_{2} \mathrm{O}$ by Thaumarchaeota affiliated with cluster B, previously reported to be a deep marine cluster (Hallam et al., 2006a) associated mainly with $\mathrm{O}_{2}$ and $\mathrm{NH}_{4}^{+}$poor waters (Molina et al., 2010). A niche separation based on $\mathrm{O}_{2}$ concentrations of cluster B affiliated AOA in the ETNA seems to be very likely, which is consistent with our data from the ETSP. Regarding the on-going decrease in dissolved $\mathrm{O}_{2}$ 


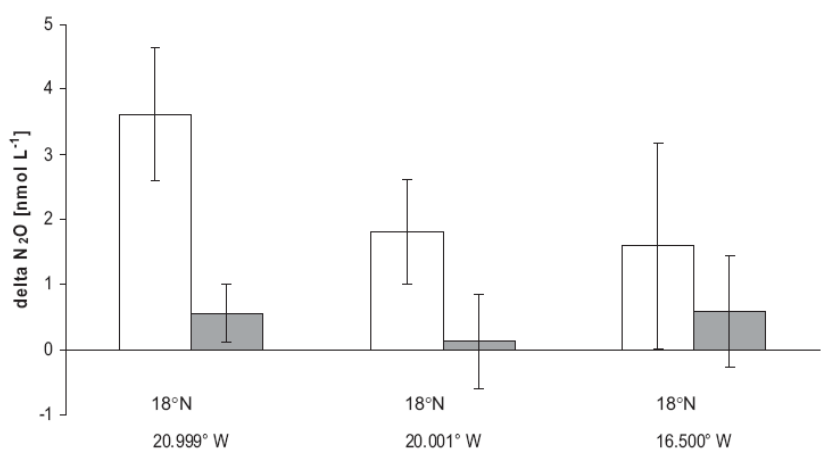

Fig. 6. $\mathrm{N}_{2} \mathrm{O}$ production determined from seawater incubations at three different stations (1-3) from the ETNA (P399). $\Delta \mathrm{N}_{2} \mathrm{O}$ was calculated as the difference of $\mathrm{N}_{2} \mathrm{O}$ concentrations over the incubation time (i.e. $24 \mathrm{~h}$ ). Open columns represent samples with no inhibitor, filled columns represent samples with the archaeal inhibitor $\mathrm{GC}_{7}$. Error bars indicate the standard deviation of three technical replicates.

concentrations in tropical ocean areas (Stramma et al., 2010), we hypothesize that cluster B affiliated AOA might dominate the production of $\mathrm{N}_{2} \mathrm{O}$ and the balance between reduced and oxidized nitrogen species in the ocean, as those organisms are likely more adapted to low $\mathrm{O}_{2}$ concentrations.

Both observed clusters were present in a similar distribution along vertical profiles during all cruises to the ETNA (Figs. 4 and 5, Table S1 in the Supplement). The community of AOA in this area appears therefore to be stable over the time investigated.

\section{$3.4 \mathrm{~N}_{2} \mathrm{O}$ production in the ETNA}

At three different stations in the ETNA, 24h seawater incubations using seawater from the $\mathrm{N}_{2} \mathrm{O}$ maximum (at the depth of the OMZ) were performed. In two out of three experiments, $\mathrm{N}_{2} \mathrm{O}$ production was significantly lower in samples treated with $\mathrm{N}^{1}$-guanyl-1,7-diaminoheptane $\left(\mathrm{GC}_{7}\right)$ (Fig. 6), a hypusination inhibitor shown to selectively inhibit the cell cycle of archaea (Jansson et al., 2000), but which appears not to affect AOB (for detailed experimental data see Sect. 2). In the third experiment performed at a coastal station, a similar trend was observed; however it was not statistically significant. These findings further support our hypothesis that $\mathrm{N}_{2} \mathrm{O}$ production in large parts of the ETNA occurs within the $\mathrm{OMZ}$ and is mainly carried out by archaea.

\section{5 $\mathrm{N}_{2} \mathrm{O}$ production in $N$. maritimus}

Direct evidence for the production of $\mathrm{N}_{2} \mathrm{O}$ by archaea was obtained from experiments with pure cultures of $N$. maritimus. The purity of the cultures was confirmed by extensive 16S rDNA analysis (see Sect. 2). N. maritimus cultures grew at comparable rates under the varying $\mathrm{O}_{2}$ conditions and showed similar nitrification rates. Production of
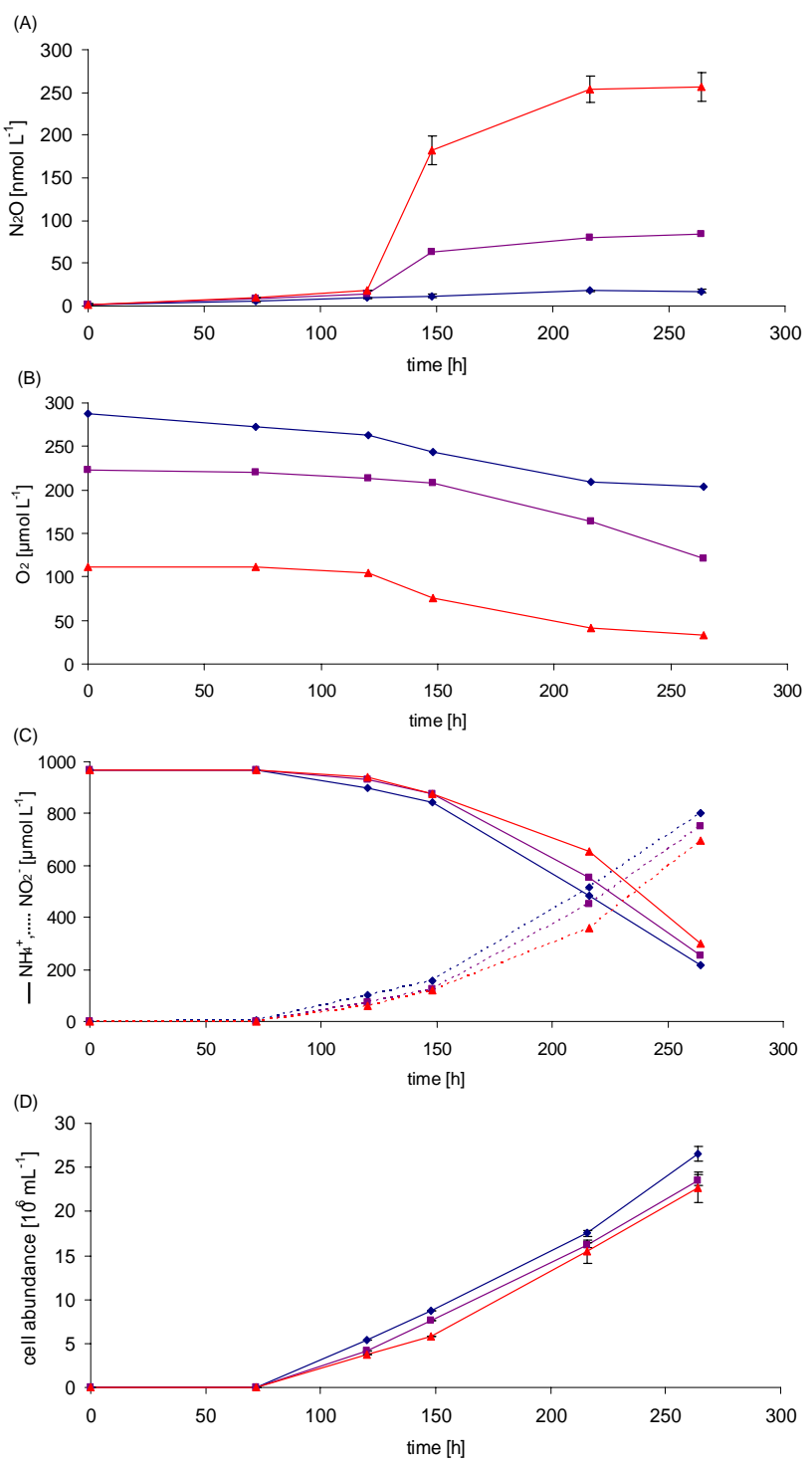

Fig. 7. $\mathrm{N}_{2} \mathrm{O}(\mathbf{A}), \mathrm{O}_{2}(\mathbf{B}), \mathrm{NH}_{4}^{+}$and $\mathrm{NO}_{2}^{-}$(C) as well as cell abundances (D) determined from incubation experiments with pure cultures of $N$. maritimus. Experiments are colour-coded according to their initial $\mathrm{O}_{2}$ concentrations: red $\left(112 \mu \mathrm{moll}^{-1}\right)$; violet $\left(223 \mu \mathrm{mol} 1^{-1}\right)$; and blue $\left(287 \mu \mathrm{mol}^{-1}\right) . \mathrm{N}_{2} \mathrm{O}$ and cell abundances were measured in triplicates and the associated error ranges are indicated (please note that in the most cases the error bars are too small to be visible in the figure).

$\mathrm{N}_{2} \mathrm{O}$ in $N$. maritimus cultures was inversely correlated to $\mathrm{O}_{2}$ concentrations (Fig. 7) which were chosen according to the $\mathrm{O}_{2}$ concentrations present along the oxycline in the ETNA $\left(112,223\right.$ and $287 \mu \mathrm{moll}^{-1}$, Fig. 1). $\mathrm{N}_{2} \mathrm{O}$ production rates from two AOB cultures (Nitrosomonas marina NM22 and Nitrosococcus oceani $\mathrm{NC10}$ ) were considerably lower compared to the $\mathrm{N}_{2} \mathrm{O}$ produced by $N$. maritimus (Fig. 7, Table 2). The $\mathrm{N}_{2} \mathrm{O}$ yields $\left(\mathrm{N}_{2} \mathrm{O} / \mathrm{NH}_{4}^{+}\right)$, which appear to result from ammonia oxidation, ranged from $0.002 \%-0.03 \%$ 
Table 2. $\mathrm{N}_{2} \mathrm{O}$ production in culture experiments: mean $\mathrm{O}_{2}$ and $\mathrm{N}_{2} \mathrm{O}$ concentrations (in triplicate samples) of pure cultures of $N$. maritimus, $N$. marina and $N$. oceani after $264 \mathrm{~h}$ incubation, the initial $\mathrm{NH}_{4}^{+}$concentration $\left(\sim 1 \mathrm{mmoll}^{-1}\right)$ was completely converted to $\mathrm{NO}_{2}^{-}$in the end of the experiment in $\mathrm{AOB}$ cultures, $\mathrm{NO}_{2}^{-}$was below the detection limit at the initial time point of the incubation.

\begin{tabular}{lllll}
\hline Culture & $\begin{array}{l}\mathrm{N}_{2} \mathrm{O}\left[\mathrm{nmoll} l^{-1}\right] \\
\text { after } 264 \mathrm{~h} \\
\text { incubation }\end{array}$ & $\mathrm{O}_{2}\left[\mu \mathrm{moll}^{-1}\right]$ & $\begin{array}{l}\mathrm{Ratio}_{2} \mathrm{O} / \\
\mathrm{NH}_{4}^{+}[\%]\end{array}$ & $\begin{array}{l}\text { Max. } \mathrm{N}_{2} \mathrm{O} \text { production } \\
{\left[\mathrm{nmol}^{-1} \mathrm{day}^{-1} 10^{-6} \mathrm{cells}^{-1}\right]}\end{array}$ \\
\hline Nitrosopumilus maritimus SCM1 & $\begin{array}{l}254.75 \pm 16.86 \\
82.63 \pm 1.89\end{array}$ & 33.5 & 0.026 & 24.27 \\
& $15.57 \pm 2.38$ & 203.2 & 0.009 & 5.6 \\
Nitrosomonas marina NM22 & $41.71 \pm 0.039$ & 44.7 & 0.002 & 0.44 \\
Nitrosococcus oceani NC10 & $14.4 \pm 0.4$ & 142.9 & 0.006 & 4.17 \\
& $36.78 \pm 1.33$ & 49.8 & 0.003 & 1.44 \\
& $11.91 \pm 0.33$ & 163.7 & 0.001 & 3.68 \\
\hline
\end{tabular}

in the culture of $N$. maritimus to $0.001 \%-0.006 \%$ in the AOB cultures. The $\mathrm{N}_{2} \mathrm{O}$ production rates per cell derived from our AOB experiments are in agreement with those reported by Goreau et al. (1980), even though a different experimental setup was used. Culture experiments, such as those presented here, were performed with AOB cell densities $\left(\sim 10^{5}\right.$ cells $\left.\mathrm{ml}^{-1}\right)$, which are much higher than usually found in the ocean $\left(10^{2}-10^{3}\right.$ cells $\mathrm{ml}^{-1}$ ) (Wuchter et al., 2006; Lam et al., 2009). Thus, the $\mathrm{N}_{2} \mathrm{O}$ production rates from the AOB cultures are probably overestimated and not representative as $\mathrm{N}_{2} \mathrm{O}$ production per cell by AOB also depends on the present cell densities (Frame and Casciotti, 2010), with high cell densities leading to enhanced $\mathrm{N}_{2} \mathrm{O}$ production. In contrast, the AOA cell densities in our culture experiment $\left(\sim 10^{5}-10^{7}\right.$ cells $\left.\mathrm{ml}^{-1}\right)$ were comparable to those present in the oceanic environment $\left(\sim 10^{5}\right.$ cells $\left.\mathrm{ml}^{-1}\right)$ and thus seem to be reasonably representative of the rates expected in natural populations of AOA.

Using the observed archaeal $\mathrm{N}_{2} \mathrm{O}$ production rate for low $\mathrm{O}_{2}$ conditions derived from our experimental results ( $140 \mathrm{nmol}^{-1} \mathrm{~d}^{-1}$; normalized to $10^{6}$ cells $\mathrm{ml}^{-1}$ yielding $\sim 24 \mathrm{nmoll}^{-1} \mathrm{~d}^{-1}$, see Table 2), an upper estimate for the potential archaeal $\mathrm{N}_{2} \mathrm{O}$ production would be around $14 \mathrm{nmol} \mathrm{m}^{-2} \mathrm{~s}^{-1}$ (however, $\mathrm{NH}_{4}^{+}$concentrations in our culture experiments were significantly higher than in the environment), assuming a thickness of about $50 \mathrm{~m}$ for the low $\mathrm{O}_{2}$ layer as typically found in the ETNA. Compared to estimates of $\mathrm{N}_{2} \mathrm{O}$ emissions from the ETNA to the atmosphere of up to $2 \mathrm{nmol} \mathrm{m}^{-2} \mathrm{~s}^{-1}$ (Wittke et al., 2010), potential oceanic archaeal $\mathrm{N}_{2} \mathrm{O}$ production might be indeed significant.

\subsection{Potential pathways for archaeal $\mathrm{N}_{2} \mathrm{O}$ production}

AOB can produce $\mathrm{N}_{2} \mathrm{O}$ from $\mathrm{NH}_{2} \mathrm{OH}$ during nitrification or from $\mathrm{NO}_{2}^{-}$during nitrifier-denitrification (Kool et al., 2010; Shaw et al., 2006). In AOA however, the pathway of ammonia oxidation is yet not understood. So far, no equivalent to the hydroxylamine-oxidoreductase, which catalyses the oxidation of $\mathrm{NH}_{2} \mathrm{OH}$ to $\mathrm{NO}_{2}^{-}$during nitrification in $\mathrm{AOB}$, has been identified (Könneke et al., 2005; Martens-Habbena et al., 2009; Walker et al., 2010), indicating that AOA likely use a different pathway than AOB do when producing $\mathrm{N}_{2} \mathrm{O}$. The detection of the nitrite reductase gene nirK in the sequenced genomes of cultured Thaumarchaeota (Walker et al., 2010) led to the theory that AOA might produce $\mathrm{N}_{2} \mathrm{O}$ by nitrifier-denitrification, which might particularly impact at low $\mathrm{O}_{2}$ concentrations. To identify the origin of $\mathrm{N}_{2} \mathrm{O}$ formation, isotopomeric studies were performed with $N$. maritimus pure cultures. Using the lowest $\mathrm{O}_{2}$ concentration of the three chosen $(112 \mu \mathrm{M})$, a ${ }^{15} \mathrm{~N}$ site preference $\left(\mathrm{SP}_{\mathrm{N}_{2} \mathrm{O}}\right)$ in $\mathrm{N}_{2} \mathrm{O}$ of $34 \pm 12 \%$ o was detected, consistent with results from AOA enrichments (Santoro et al., 2011), which is in agreement with the $\mathrm{SP}_{\mathrm{N}_{2} \mathrm{O}}$ of $\sim 33 \%$ o typically found in $\mathrm{AOB}$ cultures performing ammonia oxidation (Sutka et al., 2006) (for comparison: nitrifier-denitrification of $\mathrm{AOB}$ results in a $\mathrm{SP}_{\mathrm{N}_{2} \mathrm{O}}$ of about $0 \%$ ). Thus, our dataset points towards a production of $\mathrm{N}_{2} \mathrm{O}$ via the oxidation of $\mathrm{NH}_{4}^{+}$to $\mathrm{NO}_{2}^{-}$, potentially via an unknown intermediate as we were not able to detect $\mathrm{NH}_{2} \mathrm{OH}$ in $N$. maritimus cultures using the method described in Schweiger et al. (2007). However, taking $\delta^{18} \mathrm{O}$ data into account, Santoro et al. (2011) suggested a reduction of $\mathrm{NO}_{2}^{-}$to $\mathrm{N}_{2} \mathrm{O}$. As we have not performed $\mathrm{O}_{2}$ isotopomeric studies, we cannot exclude $\mathrm{N}_{2} \mathrm{O}$ production via nitrifier-denitrification, particularly when $\mathrm{O}_{2}$ becomes limiting as previously described for the Arabian Sea (Nicholls et al., 2007) where $\mathrm{O}_{2}$ concentrations drop far more than in our experiments (lowest $\mathrm{O}_{2}$ concentration $\sim 112 \mu \mathrm{M}$ ).

\section{Summary}

Taken together, the high abundance of archaeal amoA relative to AOB, the frequently obtained comparable patterns of $\mathrm{N}_{2} \mathrm{O}$ accumulation and archaeal amoA, the inhibition of $\mathrm{N}_{2} \mathrm{O}$ production in seawater experiments in the presence of the archaeal inhibitor $\mathrm{GC}_{7}$ as well as the $\mathrm{N}_{2} \mathrm{O}$ production by $N$. maritimus add to the mounting evidence that, in large parts of the ocean, $\mathrm{N}_{2} \mathrm{O}$ is produced by archaeal rather than by 
bacterial nitrification. Further, the archaeal $\mathrm{N}_{2} \mathrm{O}$ production appears to be highly sensitive to the dissolved $\mathrm{O}_{2}$ concentration, with highest $\mathrm{N}_{2} \mathrm{O}$ production rates at low $\mathrm{O}_{2}$ concentrations such as those present in the OMZ of the ETNA. The predicted expansion of OMZs in the future in many parts of the ocean (Stramma et al., 2008) may lead to an enhanced $\mathrm{N}_{2} \mathrm{O}$ production in the ocean (Naqvi et al., 2010) and therefore may have severe consequences for the budget of $\mathrm{N}_{2} \mathrm{O}$ in the atmosphere as well.

\section{Supplementary material related to this article is available online at: http://www.biogeosciences.net/9/ 2419/2012/bg-9-2419-2012-supplement.pdf.}

Acknowledgements. We would like to thank three anonymous referees for their constructive comments that helped to improve the manuscript. We further thank the authorities of Cape Verde, Mauritania and Peru for the permission to work in their territorial waters. We acknowledge the support of the captains and crews of $\mathrm{R} / \mathrm{V}$ Poseidon, R/V L'Atalante, and R/V Meteor as well as the chief scientists of ATA03, A. Körtzinger, and M77/3, Martin Frank. Moreover, we thank T. Kalvelage for sampling during P348, and T. Großkopf and H. Schunck for sampling during M77/3; we further thank K. Stange, F. Malien, M. Lohmann, V. Leon and P. Fritsche for oxygen and nutrient measurements. We thank A. Pommerening-Röser for providing cultures of $N$. oceani NC10 and N. marina NM22 and C. Fehling for performing the isotopomeric studies. Financial support for this study was provided by the DFG Sonderforschungsbereich 754 (www.sfb754.de) and the BMBF Verbundprojekt SOPRAN (www.sopran.pangaea.de; SOPRAN grants 03F0462A and 03F0611A). MK was financially supported by the DFG.

Edited by: M. Voss

\section{References}

Bange, H. W., Freing, A., Kock, A., and Löscher, C. R.: Marine Pathways to Nitrous Oxide, in: Nitrous oxide and Climate Change, edited by: Smith, K. A., Earthscan, London, Washington, 36-62, 2010.

Brochier-Armanet, C., Boussau, B., Gribaldo, S., and Forterre, P.: Mesophilic crenarchaeota: proposal for a third archaeal phylum, the Thaumarchaeota, Nat. Rev. Microbiol., 6, 245-252, 2008.

Bustin, S. A., Benes, V., Garson, J. A., Hellemans, J., Huggett, J., Kubista, M., Mueller, R., Nolan, T., Pfaffl, M. W., Shipley, G. L., Vandesompele, J., and Wittwer, C. T.: The MIQE Guidelines: Minimum Information for Publication of Quantitative Real-Time PCR Experiments, Clin. Chem., 55, 611-622, doi:10.1373/clinchem.2008.112797, 2009.

Church, M. J., Wai, B., Karl, D. M., and DeLong, E. F.: Abundances of crenarchaeal amoA genes and transcripts in the Pacific Ocean, Environ. Microbiol., 12, 679-688, doi:10.1111/j.14622920.2009.02108.x, 2009.
Codispoti, L. A.: Interesting Times for Marine $\mathrm{N}_{2} \mathrm{O}$, Science, 327 , 1339-1340, doi:10.1126/science.1184945, 2010.

Denman, K. L., Brasseur, G., Chidthaisong, A., Ciais, P., Cox, P. M., Dickinson, R. E., Hauglustaine, D., Heinze, C., Holland, E., Jacob, D., Lohmann, U., Ramachandran, S., da Silva Dias, P. L., Wofsy, S. C., and Zhang, X.: Couplings Between Changes in the Climate System and Biogeochemistry, in: Climate Change 2007: The Physical Science Basis. Contribution of Working Group I to the Fourth Assessment Report of the Intergovernmental Panel on Climate Change, edited by: Solomon, S., Qin, D., Manning, M., Chen, Z., Marquis, M., Averyt, K. B., Tignor, M., and Miller, H. L., Cambridge University Press, Cambridge, UK, New York, NY, 2007.

Fehling, C. and Friedrichs, G.: A precise high-resolution near infrared continuous wave cavity ringdown spectrometer using a Fourier transform based wavelength calibration, Rev. Sci. Instrum., 81, 053109 doi:10.1063/1.3422254, 2010.

Forster, P., Ramaswamy, V., Artaxo, P., Berntsen, T., Betts, R., Fahey, D. W., Haywood, J., Lean, J., Lowe, D. C., Myhre, G., Nganga, J., Prinn, R., Raga, G., Schulz, M., and Van Dorland, R.: Changes in Atmospheric Constituents and in Radiative Forcing, in: Climate Change 2007: The Physical Science Basis. Contribution of Working Group I to the Fourth Assessment Report of the Intergovernmental Panel on Climate Change, edited by: Solomon, S., Qin, D., Manning, M., Chen, Z., Marquis, M., Averty, K. B., Tignor, M., and Miller, H. L., Cambridge University Press, Cambridge, UK and New York, NY, USA, 129-234, 2007.

Frame, C. H. and Casciotti, K. L.: Biogeochemical controls and isotopic signatures of nitrous oxide production by a marine ammonia-oxidizing bacterium, Biogeosciences, 7, 2695-2709, doi:10.5194/bg-7-2695-2010, 2010.

Francis, C. A., Roberts, K. J., Beman, J. M., Santoro, A. E., and Oakley, B. B.: Ubiquity and diversity of ammoniaoxidizing archaea in water columns and sediments of the ocean, P. Natl. Acad. Sci. USA, 102, 14683-14688, doi:10.1073/pnas.0506625102, 2005.

Francis, C. A., Beman, J. M., and Kuypers, M. M. M.: New processes and players in the nitrogen cycle: the microbial ecology of anaerobic and archaeal ammonia oxidation, ISME J., 1, 1927, doi:10.1038/ismej.2007.8, 2007.

Goreau, T. J., Kaplan, W. A., Wofsy, S. C., McElroy, M. B., Valois, F. W., and Watson, S. W.: Production of $\mathrm{NO}_{2}-$ and $\mathrm{N}_{2} \mathrm{O}$ by Nitrifying Bacteria at Reduced Concentrations of Oxygen, Appl. Environ. Microb., 40, 526-532, 1980.

Grasshoff, G., Kremling, K., Erhardt, M.: Methods of seawater analysis, 3rd Edn., Wiley VCH, Weinheim, 1999.

Hallam, S. J., Mincer, T., Schleper, C., Preston, C., Roberts, K., Richardson, P., and DeLong, E.: Pathways of carbon assimilation and ammonia oxidation suggested by environmental genomic analyses of marine crenarchaeota, Plos Biol., 4, 24122412, doi:10.1371/journal.pbio.0040437, 2006a.

Hallam, S. J., Konstantinidis, K. T., Putnam, N., Schleper, C., Watanabe, Y., Sugahara, J., Preston, C., de la Torre, J., Richardson, P. M., and DeLong, E. F.: Genomic analysis of the uncultivated marine crenarchaeote Cenarchaeum symbiosum, P. Natl. Acad. Sci. USA, 103, 18296-18301, doi:10.1073/pnas.0608549103, 2006b. 
Jansson, B. P. M., Malandrin, L., and Johansson, H. E.: Cell Cycle Arrest in Archaea by the Hypusination Inhibitor N1Guanyl-1,7-Diaminoheptane, J. Bacteriol., 182, 1158-1161, doi:10.1128/jb.182.4.1158-1161.2000, 2000.

Kartal, B., Kuypers, M. M. M., Lavik, G., Schalk, J., den Camp, H., Jetten, M. S. M., and Strous, M.: Anammox bacteria disguised as denitrifiers: nitrate reduction to dinitrogen gas via nitrite and ammonium, Environ. Microbiol., 9, 635-642, doi:10.1111/j.14622920.2006.01183.x, 2007.

Könneke, M., Bernhard, A. E., de la Torre, J. R., Walker, C. B., Waterbury, J. B., and Stahl, D. A.: Isolation of an autotrophic ammonia-oxidizing marine archaeon, Nature, 437, 543-546, doi:10.1038/nature03911, 2005.

Kool, D. M., Wrage, N., Zechmeister-Boltenstern, S., Pfeffer, M., Brus, D., Oenema, O., and Van Groenigen, J.-W.: Nitrifier denitrification can be a source of $\mathrm{N}_{2} \mathrm{O}$ from soil: a revised approach to the dual-isotope labelling method, Eur. J. Soil Sci., 61, 759$772,2010$.

Lam, P., Jensen, M. M., Lavik, G., McGinnis, D. F., Muller, B., Schubert, C. J., Amann, R., Thamdrup, B., and Kuypers, M. M. M.: Linking crenarchaeal and bacterial nitrification to anammox in the Black Sea, P. Natl. Acad. Sci. USA, 104, 7104-7109, doi:10.1073/pnas.0611081104, 2007.

Lam, P., Lavik, G., Jensen, M. M., van de Vossenberg, J., Schmid, M., Woebken, D., Dimitri, G., Amann, R., Jetten, M. S. M., and Kuypers, M. M. M.: Revising the nitrogen cycle in the Peruvian oxygen minimum zone, P. Natl. Acad. Sci. USA, 106, 47524757, doi:10.1073/pnas.0812444106, 2009.

Löscher, C. R.: Sensitivity to the biological oceanic nitrogen cycle to changes in dissolved oxygen, $\mathrm{PhD}$, Microbiology, Christian Albrechts University, Kiel, Kiel, 120 pp., 2011.

Martens-Habbena, W., Berube, P. M., Urakawa, H., de la Torre, J. R., and Stahl, D. A.: Ammonia oxidation kinetics determine niche separation of nitrifying Archaea and Bacteria, Nature, 461, 976-979, doi:10.1038/nature08465, 2009.

Molina, V., Belmar, L., and Ulloa, O.: High diversity of ammoniaoxidizing archaea in permanent and seasonal oxygen-deficient waters of the eastern South Pacific, Environ. Microbiol., 12, 2450-2465, doi:10.1111/j.1462-2920.2010.02218.x, 2010.

Nakayama, T., Fukuda, H., Kamikawa, T., Sugita, A., Kawasaki, M., Morino, I., and Inoue, G.: Measurements of the $3 \mathrm{v} 3$ band of ${ }^{14} \mathrm{~N}^{15} \mathrm{~N}^{16} \mathrm{O}$ and ${ }^{15} \mathrm{~N}^{14} \mathrm{~N}^{16} \mathrm{O}$ using continuous-wave cavity ringdown spectroscopy, Appl. Phys. B-Lasers O., 88, 137-140, 2007.

Naqvi, S. W. A., Bange, H. W., Farías, L., Monteiro, P. M. S., Scranton, M. I., and Zhang, J.: Marine hypoxia/anoxia as a source of $\mathrm{CH}_{4}$ and $\mathrm{N}_{2} \mathrm{O}$, Biogeosciences, 7, 2159-2190, doi:10.5194/bg7-2159-2010, 2010.

Nevison, C., Butler, J. H., and Elkins, J. W.: Global distribution of $\mathrm{N}_{2} \mathrm{O}$ and $\mathrm{DN}_{2} \mathrm{O}-\mathrm{AOU}$ yield in the subsurface ocean, Global Biogeochem. Cy., 17, 1119, doi:10.1029/2003GB002068, 2003.

Nicholls, J. C., Davis, C. A., and Trimmer, M.: High-resolution profiles and nitrogen isotope tracing reveal a dominant source of nitrous oxide and multiple pathways of nitrogen gas formation in the central Arabian Sea, Limnol. Oceanogr., 52, 156-168, 2007.

Poth, M. and Focht, D. D.: ${ }^{15} \mathrm{~N}$ kinetic analysis of $\mathrm{N}_{2} \mathrm{O}$ production by Nitrosomas europaea: An examination of nitrifier denitrification, Appl. Environ. Microb., 49, 1134-1141, 1985.

Purkhold, U., Pommerening-Roser, A., Juretschko, S., Schmid, M. C., Koops, H. P., and Wagner, M.: Phylogeny of all recognized species of ammonia oxidizers based on comparative 16S rRNA and amoA sequence analysis: Implications for molecular diversity surveys, Appl. Environ. Microb., 66, 5368-5382, 2000.

Ravishankara, A. R., Daniel, J. S., and Portmann, R. W.: Nitrous Oxide $\left(\mathrm{N}_{2} \mathrm{O}\right)$ : The Dominant Ozone-Depleting Substance Emitted in the 21st Century, Science, 326, 123-125, doi:10.1126/science.1176985, 2009.

Rotthauwe, J. H., Witzel, K. P., and Liesack, W.: The ammonia monooxygenase structural gene $a m o A$ as a functional marker: Molecular fine-scale analysis of natural ammonia-oxidizing populations, Appl. Environ. Microb., 63, 4704-4712, 1997.

Ryabenko, E., Kock, A., Bange, H. W., Altabet, M. A., and Wallace, D. W. R.: Contrasting biogeochemistry of nitrogen in the Atlantic and Pacific Oxygen Minimum Zones, Biogeosciences, 9, 203215, doi:10.5194/bg-9-203-2012, 2012.

Saitou, N. and Nei, M.: On the Maximum-Likelihood Method for Molecular Phylogeny, Jpn. J. Genet., 62, 547-548, 1987.

Santoro, A. E., Casciotti, K. L., and Francis, C. A.: Activity, abundance and diversity of nitrifying archaea and bacteria in the central California Current, Environ. Microbiol., 12, 1989-2006, doi:10.1111/j.1462-2920.2010.02205.x, 2010.

Santoro, A. E., Buchwald, C., McIlvin, M. R., and Casciotti, K. L.: Isotopic Signature of $\mathrm{N}_{2} \mathrm{O}$ Produced by Marine AmmoniaOxidizing Archaea, Science, 333, 1282-1285, 2011.

Schleper, C.: Ammonia oxidation: different niches for bacteria and archaea?, ISME J., 4, 1092-1094, doi:10.1038/ismej.2010.111, 2010.

Schleper, C., Jurgens, G., and Jonuscheit, M.: Genomic studies of uncultivated archaea, Nat. Rev. Microbiol., 3, 479-488, doi:10.1038/nrmicro1159, 2005.

Schmid, M. C., Hooper, A. B., Klotz, M. G., Woebken, D., Lam, P., Kuypers, M. M. M., Pommerening-Roeser, A., op den Camp, H. J. M., and Jetten, M. S. M.: Environmental detection of octahaem cytochrome c hydroxylamine/hydrazine oxidoreductase genes of aerobic and anaerobic ammonium-oxidizing bacteria, Environ. Microbiol., 10, 3140-3149, doi:10.1111/j.14622920.2008.01732.x, 2008.

Schweiger, B., Hansen, H. P., and Bange, H. W.: A time series of hydroxylamine $\left(\mathrm{NH}_{2} \mathrm{OH}\right)$ in the southwestern Baltic Sea, Geophys. Res. Lett., 34, L24608, doi:10.1029/2007gl031086, 2007.

Shaw, L. J., Nicol, G. W., Smith, Z., Fear, J., Prosser, J. I., and Baggs, E. M.: Nitrosospira spp. can produce nitrous oxide via a nitrifier denitrification pathway, Environ. Microbiol., 8, 214 222, 2006.

Spang, A., Hatzenpichler, R., Brochier-Armanet, C., Rattei, T., Tischler, P., Spieck, E., Streit, W., Stahl, D. A., Wagner, M., and Schleper, C.: Distinct gene set in two different lineages of ammonia-oxidizing archaea supports the phylum Thaumarchaeota, Trends Microbiol., 18, 331-340, 2010.

Steglich, C., Lindell, D., Futschik, M., Rector, T., Steen, R., and Chisholm, S. W.: Short RNA half-lives in the slow-growing marine cyanobacterium Prochlorococcus, Genome Biol., 11, R54, doi:10.1186/gb-2010-11-5-r54, 2010.

Stein, L. Y. and Yung, Y. L.: Production, isotopic composition, and atmospheric fate of biologically produced nitrous oxide, Annu. Rev. Earth Pl. Sc., 31, 329-356, doi:10.1146/annurev.earth.31.110502.080901, 2003.

Stramma, L., Johnson, G. C., Sprintall, J., and Mohrholz, V.: Expanding oxygen-minimum zones in the tropical oceans, Science, 
320, 655-658, doi:10.1126/science.1153847, 2008.

Stramma, L., Schmidtko, S., Levin, L. A., and Johnson, G. C.: Ocean oxygen minima expansions and their biological impacts, Deep-Sea Res. Pt. I, 57, 587-595, doi:10.1016/j.dsr.2010.01.005, 2010.

Suntharalingam, P., Sarmiento, J. L., and Toggweiler, J. R.: Global significance of nitrous-oxide production and transport from oceanic low-oxygen zones: A modeling study, Global Biogeochem. Cy., 14, 1353-1370, 2000.

Sutka, R. L., Ostrom, N. E., Ostrom, P. H., Breznak, J. A., Gandhi, H., Pitt, A. J., and Li, F.: Distinguishing nitrous oxide production from nitrification and denitrification on the basis of isotopomer abundances, Appl. Environ. Microb., 72, 638-644, doi:10.1128/aem.72.1.638-644.2006, 2006.

Treusch, A. H., Leininger, S., Kletzin, A., Schuster, S. C., Klenk, H. P., and Schleper, C.: Novel genes for nitrite reductase and Amorelated proteins indicate a role of uncultivated mesophilic crenarchaeota in nitrogen cycling, Environ. Microbiol., 7, 1985-1995, doi:10.1111/j.1462-2920.2005.00906.x, 2005.

Venter, J. C., Remington, K., Heidelberg, J. F., Halpern, A. L., Rusch, D., Eisen, J. A., Wu, D., Paulsen, I., Nelson, K. E., Nelson, W., Fouts, D. E., Levy, S., Knap, A. H., Lomas, M. W., Nealson, K., White, O., Peterson, J., Hoffman, J., Parsons, R., Baden-Tillson, H., Pfannkoch, C., Rogers, Y. H., and Smith, H. O.: Environmental genome shotgun sequencing of the Sargasso Sea, Science, 304, 66-74, 2004.
Walker, C. B., de la Torre, J. R., Klotz, M. G., Urakawa, H., Pinel, N., Arp, D. J., Brochier-Armanet, C., Chain, P. S. G., Chan, P. P., Gollabgir, A., Hemp, J., Hugler, M., Karr, E. A., Konneke, M., Shin, M., Lawton, T. J., Lowe, T., MartensHabbena, W., Sayavedra-Soto, L. A., Lang, D., Sievert, S. M., Rosenzweig, A. C., Manning, G., and Stahl, D. A.: Nitrosopumilus maritimus genome reveals unique mechanisms for nitrification and autotrophy in globally distributed marine crenarchaea, P. Natl. Acad. Sci. USA, 107, 8818-8823, doi:10.1073/pnas.0913533107, 2010.

Walter, S., Bange, H. W., Breitenbach, U., and Wallace, D. W. R.: Nitrous oxide in the North Atlantic Ocean, Biogeosciences, 3, 607-619, doi:10.5194/bg-3-607-2006, 2006.

Wittke, F., Kock, A., and Bange, H. W.: Nitrous oxide emissions from the upwelling area off Mauritania (NW Africa), Geophys. Res. Lett., 37, L12601, doi:10.1029/2010GL042442, 2010.

Wuchter, C., Abbas, B., Coolen, M. J. L., Herfort, L., van Bleijswijk, J., Timmers, P., Strous, M., Teira, E., Herndl, G. J., Middelburg, J. J., Schouten, S., and Damste, J. S. S.: Archaeal nitrification in the ocean, P. Natl. Acad. Sci. USA, 103, 12317-12322, doi:10.1073/pnas.0600756103, 2006.

Yoshida, N., Morimoto, H., Hirano, M., Koike, I., Matsuo, S., Wada, E., Saino, T., and Hattori, A.: Nitrification Rates and $\mathrm{N}^{15}$ Abundances of $\mathrm{N}_{2} \mathrm{O}$ and $\mathrm{NO}_{3}^{-}$in the Western North Pacific, Nature, 342, 895-897, 1989. 